\begin{tabular}{|l|l|l||}
\hline \multicolumn{2}{|c|}{ PublisherInfo } \\
\hline \hline PublisherName & $:$ & BioMed Central \\
\hline \hline PublisherLocation & $:$ & London \\
\hline \hline PublisherImprintName & $:$ & BioMed Central \\
\hline \hline
\end{tabular}

\title{
Defining relevance
}

\begin{tabular}{|l|l|l||}
\hline \multicolumn{2}{|c|}{ ArticleInfo } \\
\hline \hline ArticleID & $:$ & 3803 \\
\hline \hline ArticleDOI & $:$ & $10.1186 /$ gb-spotlight-20001018-03 \\
\hline \hline ArticleCitationID & $:$ & spotlight-20001018-03 \\
\hline \hline ArticleSequenceNumber & $:$ & 240 \\
\hline \hline ArticleCategory & $:$ & Research news \\
\hline ArticleFirstPage & $:$ & 1 \\
\hline \hline ArticleLastPage & $:$ & 2 \\
\hline \hline & $:$ & RegistrationDate : 2000-10-18 \\
ArticleHistory & $:$ & OnlineDate \\
\hline \hline ArticleCopyright & $:$ & BioMed Central Ltd2000-10-18 \\
\hline \hline ArticleGrants & $:$ & \\
\hline \hline ArticleContext & $:$ & 130591111 \\
\hline \hline
\end{tabular}


William Wells

Email:wells@biotext.com

In the October 24 Proceedings of the National Academy of Sciences Butte et al. propose that relevance networks could provide a better way of analyzing genomic information than phylogenetic trees (Proc Natl Acad Sci USA 2000, 97, published online ahead of print). Phylogenetic trees derived from array experiments can only link a gene to one other gene, typically the one that is most strongly correlated in its expression pattern. In contrast, the method presented by Butte et al. can group any number of genes in associations of varying strength, can identify negative correlations, and can group disparate types of biological measurements (in this case, gene expression levels and susceptibility to cancer drugs). Butte et al. analyze the baseline expression level of 7,245 genes in the National Cancer Institute's standard collection of 60 human cancer cell lines. They correlate these measurements with the inhibition of growth of the same cell lines in response to 5,084 different anticancer agents. The resultsinclude clusters of drugs with similar modes of action, clusters of genes with similar functions, and the grouping of one drug with the gene for a tumor-associated actin-binding protein. Spurious associations are eliminated by repeated random permutation testing to define the upper threshold for chance observations.

\section{References}

1. Proceedings of the National Academy of Sciences, [http://www.pnas.org/]

2. Cluster analysis and display of genome-wide expression patterns.

3. An information-intensive approach to the molecular pharmacology of cancer.

4. Supplementary Material for Manuscripts, [http://www.chip.org/genomics]

This PDF file was created after publication. 